\title{
Effects of Exchange Rate Shocks and Political Risk on the Turkish Manufacturing Industry: Some Evidence
}

\author{
Üzeyir Aydin ${ }^{1}$, Ramazan Ekinci², Osman Tüzün ${ }^{3, *}$ \\ ${ }^{1}$ Department of Economics, Faculty of Economics and Administrative Sciences, Dokuz Eylul University, Turkey \\ ${ }^{2}$ Department of Economics, Faculty of Economics and Administrative Sciences, Bakircay University, Turkey \\ ${ }^{3}$ Department of Economics, Faculty of Economics and Administrative Sciences, Usak University, Turkey
}

Received January 15, 2020; Revised April 9, 2020; Accepted May 13, 2020

Copyright $\mathrm{O} 2020$ by authors, all rights reserved. Authors agree that this article remains permanently open access under the terms of the Creative Commons Attribution License 4.0 International License

\begin{abstract}
In cases where debt dollarization of firms is more than asset dollarization, sudden and high depreciation of the national currency causes firms to lose net wealth and may adversely affect their investments and profitability. Real exchange rate depreciation, on one hand, increases the incomes of manufacturing industry firms by providing international competitive advantage and it can prevent the competitive advantage by creating negative balance sheet effect due to high debt dollarization on the other. In this context, the aim of this study is to discuss the determinants of the debt-dollarization and the balance sheet situation of the manufacturing industry, which is facing political instability and exchange rate volatility. Dynamic panel data method was used for manufacturing industry sub-sector data for the 2008-2015 period. Overall, our empirical results reveal that the exchange rate shocks have positive impact on both debt dollarization and profitability. That means there is an exchange rate dependency in manufacturing industry. In addition, results show that there is no significant effect of political uncertainty on debt dollarization and the profitability of firm.
\end{abstract}

Keywords Debt Dollarization, Political Instability, Manufacturing Industry, GMM

\section{Introduction}

Financial resources are required to make the investments that underpin economic growth and development. Investments increase with the availability of adequate funding and the efficient use of these sources by the real sector. Thus, it is possible to enhance the level of employment and increase output. When financial resources are insufficient, economic development slows down and the desired level of economic progress cannot be reached.

Creating resources for the real sector and directing to investments is one of the main priorities of the economy, both in terms of growth and development. Low savings and low profitability due to the poor internal resource creation potential, restricts investments and growth, thus causing the need for outsourcing. The insufficiency of domestic savings; the dependence of industrial production on imports of intermediate goods, raw materials and investment goods, and the fact that the maturity of foreign debts must be converted by external borrowing can be listed as the main determinants of the external financing needs of developing countries (Mutlu, 2011).

External financing reduces the savings restriction on investments, increases efficiency and capacity growth, creates balance sheet-based vulnerabilities and instability, such as debt dollarization; all of which pose a threat to sustainable growth. For this reason, the structure and the extent of the assets and liabilities of the firms' is a significant cause of financial fragility. On the other hand, political instability, internal turmoil, geographical closeness to areas of regional conflict, loss of international investor confidence; make it difficult or impossible to obtain new financing or to return to existing short-term liabilities. In this situation, the sharp decline in the demand for financial assets could give rise to a remarkable increase in the demand for outsourcing and foreign currency assets. The adjustment process may occur in the context of large capital outflows, a large depreciation of the national currency, a shrinking current account deficit or a current account surplus and economic recession (Mutlu, 2011). In developing countries, such as Turkey, where the national currency suddenly depreciates, the borrowing costs and real debt services of firms in foreign currency increase and the net balance sheet deteriorates. Particularly when the assets are held in the national currency, the debt burden of such economic units 
increases (Incekara et al. 2017).

If the debt dollarization of firms is higher than the dollarization of assets, firms lose their net wealth and the real investments adversely affected. This situation continued to demonstrate itself with the financial crises in East Asia, Latin America and Turkey in the following years, which began in Mexico in 1994 (Aklan \& Nargelecekenler, 2010). "Third-generation" crisis models developed as a result of these crises and based on the balance sheet approach also reveal how capital movements can lead to currency crises and financial crises (Dornbusch, 2001). While these crises and crisis models were discussed in the academic literature, the 2007/08 crisis emerged as a result of the shift of capital to the financial sector to compensate for the shrinking profit rates in the real sector on a global scale. Ultimately, the Fed has begun a large-scale asset purchase program as part of "quantitative easing (QE)" and credit expansion strategies. With this policy, the assets in the private sector portfolio, which are facing the risk of bankruptcy, have been transferred to the FED side. The cost of this policy was the large-scale expansion of the FED's balance sheet. Eventually, the FED's asset purchase program and interest policy became questionable when the financial inflation induced by the FED-market maker function, which was not shielded by high returns, started to create conditions for the emergence of a new financial crisis.

FED's policy, which is based upon ending the asset purchase program, selling the toxic assets and raising the interest rate, reduces the value of the currencies of the developing countries against the dollar while increasing the uncertainty in the foreign exchange market. Therefore, the financial structure of firms is becoming very susceptible to global financial shocks and policy developments, political developments, and the resulting high real exchange rate volatility. At the micro level, the increase in the real exchange rate can increase the liabilities of the firms over foreign currency, negatively affecting investment and production decisions. This channel indicates the "balance sheet effect" of exchange rate changes. Thus, the effects of real exchange rate fluctuations and capital flows can be examined, on the balance sheet structure of firms at both macro and micro levels. If the balances of manufacturing firms with high debt dollarization and low export rates are not shielded against exchange rate risk, the real exchange rate fluctuations may cause them to shrink their investments and lead to challenges in payments.

The purpose of this study is to address the determinants of debt dollarization of manufacturing industry and its impact on the balance sheet, the profitability of firms in the face of political instability and exchange rate volatility. The rest of the study is organized as follows. The following section addresses the literature on debt dollarization and political instability and its effects on the balance sheet and economic growth. The financial structure of the real sector is presented in the third section. Finally, in the last section, using manufacturing industry data, the effect of exchange rate shocks and political instability on the manufacturing industry is analyzed by econometric methods.

\section{Literature Review}

According to the Mundell-Fleming model, which is the fundamental theoretical approach in economics, real exchange shocks affects the economy through exports and imports (net exports). The theory suggests that, if the Marshall-Lerner condition holds and the increase in production in the exporter sectors is higher than the contraction in other sectors, the value of the domestic currency depreciates. Consequently, it will increase the net exports by improving the competitiveness of the export units without affecting the financial assets/liabilities and contributes to economic growth. Since the Mundell-Fleming model does not consider the debt dollarization, open positions and the imported input composition of the economy, it cannot expect that shock depreciation in the domestic currency may worsen the financial situation of the economic units and lead to an economic recession. It is demonstrated in the literature that the devaluation, which is the main policy recommendation of the model, has been seen in many emerging countries as the cause of a high real income reduction, a real increase in the value of debt and the cost of borrowing (Frankel 2005; Bebzcuk et al 2006; Ozmen \& Yalçın 2007; Bleakley \& Cowan 2008; Alp \& Yalcin 2015; Incekara et al. 2017).

Contrary to the prediction of the Modigliani-Miller theorem, which was developed on the Mundell-Fleming formation and argued that the capital structure of the firm would not affect the capital cost and firm value, it is generally accepted that financial shocks could affect the financial assets/liabilities of firms, households and financial markets (Krugman 1999, Cespedes et al. 2004, Gertler et al. 2007, Aghion et al. 2001, Allen et al. 2002).

Several channels on how exchange rate volatility and the depreciation of domestic currency affect businesses are presented as follows. The first of these is through the balance sheet effect. The second is that sometimes the expansionary monetary policy, implemented in response to the recession, further deepens the balance sheet crisis as it accelerates the depreciation of the domestic currency (Krugman 1999; Aghion et al. 2001; Allen et al. 2002; Calvo \& Reinhart 2002; Calvo et al. 2004; Obstfeld 2009; Alp \& Yalcin 2015; Incekara et al. 2017). The third channel is the sector in which the firm is located, the characteristics of the firm and the composition of the foreign exchange balance sheet (Galindo et al. 2003). Therefore, in case of a sharp decrease in the value of the domestic currency, the balance sheets of foreign currency 
borrower firms in sectors with high domestic market share could be worsened and the entire economy could become vulnerable (Alp \& Yalcin, 2015). In this context, the impact of borrowing in foreign currencies on the balance sheets is particularly important in terms of directing monetary and exchange rate policies in emerging markets (Kesiyeli et al. 2005).

While microeconomic studies on the determinants of borrowing in foreign currencies and their effects on firm growth performance are limited, a brief review of the determinants of firms' debt dollarization rate can be presented as follows;

According to Eichengreen \& Hausmann (1999) and Levy-Yeyati \& Rey (2006), in countries where savings are inadequate and financial markets are shallow, firms generally prefer taking the exchange rate risk to avoid the interest burden, stemming from their short-term liabilities.

Political instability and lack of confidence due to tensions in nearby countries (Calvo \& Reinhart 2002); ambiguities in macroeconomic policies, institutional capacity and regulations (Zettelmeyer et al. 2010); generating export revenue (Bleakley \& Cowan 2008), the exchange rate regime implemented in the country (Cespedes et al. 2004; Martinez \& Werner 2002; Cowan et al. 2005), Kamil 2012) are regarded as other determinants.

In the above studies, it was emphasized that foreign currency borrowings alleviate the financial constraints of the firms, but it was suggested that these debts had negative effects on the investments and growth, especially in periods of recession. On the other hand, there are studies supporting the view that firms with foreign currency debts provide protection against exchange rate fluctuations and that the effects of these fluctuations on real activities may be limited and may affect positively in expansion periods (Bleakley \& Cowan 2008; Aguiar 2005; Ranciere et al. 2010; Kalemli-Ozcan et al. 2009; Bougheas et al. 2012; Incekara et al. 2017). Although the literature suggests that exchange rate shocks can negatively affect the real activities of firms, outcomes may differ from country to country and from period to period (Alp \& Yalcin, 2015). At the same time, political instability causes political uncertainty and risk, restricting economic units from predicting their future, and thus potentially influencing sectoral and microeconomic areas (Sanlisoy et al. 2016). It is expected that the growth performance and profitability of companies in Turkey will be negatively affected by political instability. This study contributes to the literature on the impact of foreign currency borrowings on the financial structure and profitability. In this context, the study is important in terms of understanding the size, determinants, and effects of debt dollarization, assessing possible fragilities and establishing policy proposals.

\section{Financial Structure and Debt Dollarization of Turkish Real Sector}

Why is the share of savings in income low? Why can't individuals achieve optimum savings? Why do individuals reduce their consumption in retirement? Why do individuals with credit card debt have illiquid assets? Why do household savings fall? Behavioural economics aims to develop neoclassical theories by investigating such questions.

According to TurkStat's "Statistics on Small and Medium-Sized Enterprises (2015)", 95\% of companies in Turkey are micro-scaled. 4 percent of the remaining firms are small, and 1 percent is large scale. Small and Medium Enterprises (SMEs) account for $99.8 \%$ of the total number of enterprises, $74.2 \%$ of employment, $54.7 \%$ of wages and salaries, $63.8 \%$ of turnover, $52.8 \%$ of value added at factor cost, $53.3 \%$ of gross investment and $60 \%$ of total exports. On the other hand, the weight of SMEs on a sectoral basis is very high. SMEs account for $99.9 \%$ of total enterprises in agriculture, $98.6 \%$ in industry and $98.5 \%$ in trade and services.

The financial resources of the companies are presented in Table 1. Accordingly, in the composition of firms' external financing, the annual resource provided through shares, is around 5\%. In the 2005-2011 periods, it was observed that companies could not benefit from the alternative to provide financing through bond issues. This was because the public sector, which was in high need of borrowing, crowded the private sector out from the capital market, and the lenders preferred to make short-term investments due to economic instability. Another factor that affected the corporate bond market negatively was the fact that GDSs were exempted from tax while private sector bonds were subject to a $10 \%$. Since 2011 , there has been a relative rise in this type of financing. This is because inflation started to decline from 2005 and that the public sector borrowing requirement declined relatively and the interest rates started to decline. 
Table 1. Foreign Financing Structure of the Real Sector in Turkey (\%)

\begin{tabular}{|c|c|c|c|c|c|c|c|c|c|c|c|}
\hline & $\mathbf{2 0 0 5}$ & $\mathbf{2 0 0 6}$ & $\mathbf{2 0 0 7}$ & $\mathbf{2 0 0 8}$ & $\mathbf{2 0 0 9}$ & $\mathbf{2 0 1 0}$ & $\mathbf{2 0 1 1}$ & $\mathbf{2 0 1 2}$ & $\mathbf{2 0 1 3}$ & $\mathbf{2 0 1 4}$ & $\mathbf{2 0 1 5}$ \\
\hline Bank Loans & 91.2 & 91 & 91.1 & 91.3 & 92.2 & 93.2 & 92.7 & 92 & 91.1 & 92 & 90 \\
\hline Leasing Liabilities & 2.2 & 3.1 & 3.9 & 4.1 & 2.6 & 2.3 & 2.5 & 2.6 & 2.4 & 2.7 & 2.5 \\
\hline Issued Bonds & 0 & 0.07 & 0.17 & 0.21 & 0.17 & 0.37 & 0.88 & 1.75 & 2.1 & 2.12 & 2.5 \\
\hline Other Securities & 0 & 0 & 0 & 0 & 0 & 0.17 & 0.15 & 0.21 & 0.2 & 0.22 & 0.24 \\
\hline Other Financial Debts & 6.5 & 5.7 & 5 & 4.5 & 5.1 & 4.2 & 4.4 & 4.6 & 5.1 & 4.7 & 5.2 \\
\hline
\end{tabular}

Source: Prepared by the authors using CBRT sector balance sheets and Capital Markets Board's annual reports.

The abundance of resources in foreign markets has also been effective in the decline of interest rates in Turkey. Since 2006, companies have been able to obtain financing from the capital market through issuance of bonds again. Nevertheless, as it is inferred from these data, it is seen that companies in Turkey do not benefit much from the alternative of providing domestic financing, through capital market instruments such as stocks and bonds. Accordingly, among the financial resources used by the corporate sector in the period of 2003-2015, the weight of bank loans varied between $90 \%$ and $93 \%$ and reached the highest level in 2010 with $93.2 \%$. Approximately $75-80 \%$ of these are domestic bank loans and 10-15\% range is foreign bank loans. Bank loans used by the firms constitute approximately $60 \%$ of the total assets. The weight of the financial leasing increased steadily to $4.1 \%$ until 2008 and declined to around $2.5 \%$ as of 2015. The reduction in the share of these resources after 2008 was effective in the removal of value-added tax advantage at the end of 2007.

According to CBRT sector balance sheets (2015) companies in Turkey cover $38.7 \%$ of their total funding resources by their operations, $28.7 \%$ by short-term foreign sources, $28.6 \%$ by long-term foreign sources, $2.3 \%$ from equity growth and $1.7 \%$ from equity issuance premiums. According to Table 2, firms finance their investments with foreign resources (leverage ratio) of $61.8 \%$ and equity of $38.2 \%$. The height of the leverage ratio in the financing type is remarkable. This increases the financial risk of firms. However, the statutory regulation, which came into force in July 2015 and gives firms a tax advantage in equity raising, is expected to reduce leverage ratios in the coming period. As can be seen from the same table, $14.2 \%$ of the GDP is borrowed from abroad and $56.1 \%$ from domestic loans. It can be said that as firm scale increases, foreign credit cost and exchange rate volatility decrease relatively, there is a tendency towards foreign currency in firm loans and debt dollarization of firms increases. In this respect, the foreign exchange deficit of the real sector is around 28 percent of GDP. This situation is important as it reveals the exchange rate risk of the real sector and the motivation of this study.

Table 2. Real Sector Financing Developments in Turkey (\%)

\begin{tabular}{|c|c|c|}
\hline \multirow{2}{*}{ Financing Type (2014, Percent) } & Foreign Resources / Total Assets & 61.8 \\
\hline & Shareholders' Equity / Total Assets & 38.2 \\
\hline \multirow{3}{*}{ Financing Structure (2016, Percent) } & Foreign / GDP & 14.2 \\
\hline & Domestic / GDP & 56.1 \\
\hline & Foreign exchange open position / GDP & 27.9 \\
\hline \multirow{4}{*}{$\begin{array}{l}\text { Domestic Firm Loans by Firm Size } \\
\text { (2016, Percent)-TL }\end{array}$} & Micro & 15.6 \\
\hline & Small & 18.4 \\
\hline & Medium & 19.0 \\
\hline & Large & 46.7 \\
\hline \multirow{4}{*}{$\begin{array}{l}\text { Domestic Firm Loans by Firm Size } \\
\text { (2016, Percent)-Foreign Exchange }\end{array}$} & Micro & 2.6 \\
\hline & Small & 5.5 \\
\hline & Medium & 9.2 \\
\hline & Large & 82.6 \\
\hline \multirow{3}{*}{$\begin{array}{l}\text { Factors Affecting the Supply of Firm } \\
\text { Loans According to CBRT Bank Loans } \\
\text { Tendency Survey (2016, Percent) }\end{array}$} & Expectations about General Economic Activity & -58 \\
\hline & Industry or Firm Outlook & -48 \\
\hline & Risks Related to Collateral Requested & -29 \\
\hline \multirow{4}{*}{$\begin{array}{l}\text { Factors Affecting the Loan Demand } \\
\text { According to CBRT Bank Loans } \\
\text { Tendency Survey (2016, Percent) }\end{array}$} & Investments & -55 \\
\hline & Stock Increase and Working Capital & -15 \\
\hline & Mergers / Acquisitions and Restructuring & -40 \\
\hline & Debt Restructuring & +8 \\
\hline
\end{tabular}

Source: CBRT Sector Balance Sheets and CBRT Financial Stability Report (2016). 
As it is seen in the distribution of real sector loans by firm types, foreign currency loans are concentrated in relatively large companies. The share of SMEs in TL loans is higher. While the share of SMEs in TL loans is around 53 percent, this ratio is around 17 percent in foreign currency loans. The relatively low FX revenues of SMEs and the cautious attitude of banks are considered to be the determinants of this distribution (CBRT Financial Stability Report, 2016: 27).

According to the CBRT's "Bank Loan Tendency Survey", the factors affecting the supply of company loans remain quite low. The low level of credit supply levels of banks has been affected by the negative expectations regarding the general economic activity and sectoral credit risks caused by the July 15 coup attempt and terror events which have recently become a risk factor. On the other hand, relatively declining capital adequacy ratios of banks are also thought to play a role in tightening standards. Due to increased risk perceptions, banks are taking a cautious stance on lending by tightening term and guarantee conditions and restricting the amount accepted per application. There is similarly contraction on the demand side. Here it appears that the only factor increasing the demand for credit is debt restructuring (CBRT Financial Stability Report, 2016).

\section{Data and Model}

The dataset used in the study belongs to an average of 7 thousand companies operating in 15 sub-sectors for the period 2008-2015. We use CBRT's "Sectoral Balance Sheets" as a primary source of data for this study. CBRT's "Sectoral Balance Sheets" is the most comprehensive data set for the real sector companies in Turkey. The dataset covers almost all the large companies operating in the manufacturing industry.

The data set covers almost all major companies operating in the manufacturing industry. Also, companies in this dataset account for about 75 percent of company employment with 10 or more employees. Similarly, these companies account for more than two-thirds of the total manufacturing industry exports. Because the companies included in the dataset have a high weight in economic activity, the power of analysis is expected to be high.

In this study, besides the accounting information such as the balance sheet and income table of the companies, there is also information such as establishment date, average number of employees, activity status, legal status such as the main sector and sub sector in which the companies operate. Variables and definitions used in the study are presented in Table 3.

Table 4 presents the summary of descriptive statistics of all variables included in analysis and explained in Table 3.

Table 3. Variable Definition

\begin{tabular}{|c|c|c|c|}
\hline Variables & Symbol & Description & Data Source \\
\hline \multicolumn{4}{|l|}{ Firm Specific Variables } \\
\hline Debt dollarization rate & DDR & FX denominated loans / Total cash loans $* 100$ & Sectoral Balance sheets \\
\hline Export rate & EX & Total Exports / Total net sales * 100 & Sectoral Balance sheets \\
\hline Net tangible assets & NTA & Net tangible assets / Total Assets $* 100$ & Sectoral Balance sheets \\
\hline Leverage ratio & LR & Total Debt / Total Equity * 100 & Sectoral Balance sheet \\
\hline Profitability & PRO & Net Profit / Total Assets & Sectoral Balance sheets \\
\hline \multicolumn{4}{|l|}{ Macroeconomic Variables } \\
\hline Political instability indicator & PRI & & The PRS Group, ICRG \\
\hline Inflation rate & $\mathrm{INF}$ & Logarithm difference of the CPI index & TURKSTAT \\
\hline Reel Exchange Rate & $\triangle \mathrm{REER}$ & The log-difference of the CPI based Real Exchange Rate Index & CBRT \\
\hline
\end{tabular}

Table 4. Descriptive Statistics of the Variables

\begin{tabular}{|c|c|c|c|c|c|}
\hline Variable & Obs. & Mean & Std. Dev. & Min. & Max. \\
\hline DDR & 120 & 0.566 & 0.193 & 0.132 & 0.975 \\
\hline EX & 120 & 0.273 & 0.157 & 0.039 & 0.613 \\
\hline NTA & 120 & 25.060 & 8.039 & 8.084 & 43.061 \\
\hline LR & 120 & 57.202 & 8.288 & 32.488 & 74.534 \\
\hline PRO & 120 & 3.873 & 4.121 & -6.358 & 25.549 \\
\hline PRI & 120 & 43.630 & 2.775 & 39.5 & 47.833 \\
\hline INF & 120 & 7.997 & 1.563 & 6.16 & 10.45 \\
\hline$\Delta$ REER & 120 & -0.021 & 0.059 & -0.117 & 0.094 \\
\hline
\end{tabular}


In the study, the determinants of debt dollarization of 15 sub-sectors operating in the Turkish manufacturing industry and the effects of dollarization on sector performance were tested within the framework of regression analysis. Estimators were obtained with dynamic panel data models since there were lagged dependent variables among the explanatory variables. We use the system GMM estimator developed by Arellano and Bover (1995) and Blundell and Bond (1998). In static panel data models, the correlation of the firm-specific effects with the lagged dependent variable creates a bias in the usual least squares dummy variable estimator. But, the system GMM approach overcomes this problem. In this approach, two equation involved in one system. While the first equation includes the first differences of the endogenous variables, second equation contains the levels of the endogenous variables (Arellano and Bover, 1995). Also, this method has been adopted because of the endogeneity problem between explanatory variables and the error term. In the GMM estimation, the use of all available lagged levels of the variables leads to an expansion in the number of instruments, which reduces the efficiency of the estimator in finite samples (Arellano and Bover, 1995). In addition, the use of large number of instruments may weaken the Hansen J-test of over-identifying restrictions. On the other hand, restricting the instrument set too much results in a loss of information (Roodman, 2009:98-99). For this reason, we follow the method suggested by Roodman (2009) to deal with the problem of weak and excessively numerous instruments. In this method, we check the validate of system GMM by applying a second-order serial correlation test for the residuals and the Hansen J-test for the overidentifying restrictions. We expect that there is high first-order autocorrelation, but no evidence for significant second-order autocorrelation. Also, the Hansen J-test result should indicate the validity of internal instruments used in the dynamic model (Roodman, 2009:97).

In the system GMM method, as the standard errors from the two-step variant are known to be downward biased in small samples, we apply the one-step version of the system GMM estimator to obtain robust results (Arellano and Bover, 1995). Following Alp \& Yalçın (2015) and Echeverry et al. (2003), the Model 1 specification can be expressed as follows;

$$
\begin{aligned}
& \mathrm{DDR}_{\mathrm{i}, \mathrm{t}}= \beta_{1} \mathrm{DDR}_{\mathrm{i}, \mathrm{-l}-1}+\beta_{2} \mathrm{EX}_{\mathrm{i}, \mathrm{t}}+\beta_{3} \mathrm{NTA}_{\mathrm{i}, \mathrm{t}}+\beta_{4} \mathrm{LR}_{\mathrm{i}, \mathrm{t}}+\beta_{5} \mathrm{PR} \\
& \mathrm{I}_{\mathrm{t}}+\beta_{6} \mathrm{INF}_{\mathrm{t}}+\beta_{7} \Delta \mathrm{REER}_{\mathrm{t}}+\mu_{\mathrm{i}}+\eta_{t}+\varepsilon_{i, t}
\end{aligned}
$$

Where, $i$ and $t$ refer to the cross-section and the time dimension respectively. The lagged dependent variable (DDRi,t-j) in the model is the financial adjustment of dollarization, it has been used to test dynamic effects.

Other variables used in model are export rate, net tangible assets, leverage ratio, political uncertainty, inflation rate and changes of real exchange rate.
Descriptive information about the variables is given in table 3. The coefficients $\mu_{i}$ and $\eta_{t}$ denote the time-invariant firm specific effects and the time effects controlling for common shocks, respectively. $\varepsilon_{i, t}$ is an idiosyncratic error term that satisfies the standard assumptions of zero mean and constant variance. To account for possible heteroscedasticity, robust standard errors are calculated.

Model 2 was used to estimate the parameters affecting the performance/asset profitability of 15 sub-sectors operating in the manufacturing industry in Turkey. Following the studies of Bleakley \& Cowan (2008), Cowan et al., (2005), and Alp \& Yalçın (2015), Model 2 can be expressed as follows:

$$
\begin{aligned}
& \mathrm{PRO}_{\mathrm{it}}=\beta_{1} \mathrm{PRO}_{\mathrm{i}, \mathrm{t}-1}+\beta_{2}\left(\mathrm{EXX}_{\mathrm{it}}{ }^{*} \Delta \mathrm{REER}\right)+\beta_{3}\left(\mathrm{DDR}_{\mathrm{it}-1}{ }^{*} \Delta \mathrm{REER}\right)+\beta_{\mathrm{t}} \mathrm{PRI}_{\mathrm{t}}+\beta_{5} \Delta \mathrm{REE} \\
& \mathrm{R}_{\mathrm{t}}{ }^{+} \mu_{i}+\eta_{t}+\varepsilon_{i, t}
\end{aligned}
$$

Where, PRO is calculated as the ratio of net profit to total assets and used as an indicator representing the profitability of firms. $\mathrm{DDR}_{\mathrm{it}-1} * \Delta \mathrm{REER}_{\mathrm{t}}$ reflects the balance sheet effect and $\mathrm{EX}_{\mathrm{it}}{ }^{*} \triangle \mathrm{REER}_{\mathrm{t}}$ reflects the competitive effect. The $\left(\triangle \mathrm{REER}_{\mathrm{t}}\right)$ and $(\mathrm{PRI})$ parameters also show the effect of real exchange rate changes and political instability on the sector's asset profitability, respectively. Besides, the lagged value of the dependent variable is included in the model to take into account the dynamics that affect active profitability.

\section{Empirical Findings}

The results of system GMM for model 1 and 2 are presented in Table 5. Firstly, the validity of the GMM technique is tested. According to the Wald test statistics, the overall parameters of model was found to be significant level. So, the overall parameters of model was found to be significant. Secondly, the validity of instrumental variables was examined using the Hansen test. According to the Hansen test statistics, the null hypothesis was accepted, and the result is that the instrumental variables are valid. Also, as expected, we find that there is high first-order autocorrelation, but no evidence for significant second-order autocorrelation. 
Table 5. One-stage system GMM

\begin{tabular}{|c|c|c|}
\hline \multirow{2}{*}{ Variable } & Model I & Model II \\
\hline & Dep.Var.: DDR & Dep.Var.: PRO \\
\hline $\mathrm{DDR}_{\mathrm{t}-1}$ & $\begin{array}{c}0.831 * * * \\
(0.029) \\
\end{array}$ & \\
\hline $\mathrm{PRO}_{\mathrm{t}-1}$ & & $\begin{array}{c}0.607 * * * \\
(0.083)\end{array}$ \\
\hline $\mathrm{DDR}_{\mathrm{t}-1} * \Delta \mathrm{REER}$ & & $\begin{array}{c}-0.251 * * * \\
(0.083)\end{array}$ \\
\hline EX & $\begin{array}{l}0.192 * * \\
(0.093) \\
\end{array}$ & \\
\hline $\mathrm{EX} * \triangle \mathrm{REER}$ & & $\begin{array}{c}0.002 \\
(0.078)\end{array}$ \\
\hline NTA & $\begin{array}{l}0.003 * * \\
(0.001)\end{array}$ & \\
\hline LR & $\begin{array}{l}0.001 * * \\
(0.0004)\end{array}$ & \\
\hline PRI & $\begin{array}{l}-0.0006 \\
(0.004) \\
\end{array}$ & $\begin{array}{c}0.036 \\
(0.028)\end{array}$ \\
\hline INF & $\begin{array}{c}0.035^{* *} \\
(0.016)\end{array}$ & \\
\hline$\triangle \mathrm{REER}$ & $\begin{array}{l}0.441^{* *} \\
(0.212)\end{array}$ & $\begin{array}{c}17.857 * * \\
(6.355)\end{array}$ \\
\hline Constant & $\begin{array}{c}-0.322^{* *} \\
(0.119) \\
\end{array}$ & $\begin{array}{c}3.749 * * * \\
(1.401) \\
\end{array}$ \\
\hline$A R(1)$ (p-value) & 0.012 & 0.003 \\
\hline$A R(2)(p$-value $)$ & 0.339 & 0.126 \\
\hline Hansen (p-value) & 0.984 & 0.994 \\
\hline Wald (p-value) & 0.000 & 0.000 \\
\hline Number of observations & 120 & 120 \\
\hline
\end{tabular}

We use the one-step system GMM estimator with Windmeijer's (2005) corrected standard errors (reported in brackets). ***, **, and * indicate that p is less than $0.01,0.05$, and 0.1 , respectively. The Hansen test of the overidentifying restrictions for the GMM estimators is the null hypothesis that instruments used are not correlated with the residuals, and hence the overidentifying restrictions are valid. The Arellano-Bond (AB) test for serial correlation concerns the first differenced residuals. The null hypothesis is that errors in the first difference regression do not exhibit second-order serial correlation. The results given in brackets for the Hansen test and AR (1) -AR (2) are probability values.

According to the empirical results, as shown in table 5, the signs of the firm-specific and macroeconomic condition variable coefficients appear to be expected. The one-term lagged value of the dependent variable is positive and statistically significant for the manufacturing industry. This indicates that the debt dollarization depends on past values and that there is a persistency.

The direction of the balance sheet effect of FX-denominated loans depends on whether the FX-denominated loans are comparable with the foreign currency composition of the company's incomes. In this context, the export ratio (EX) is aimed to test whether there is a relationship between the foreign exchange composition of the company's debt and the ratio of the company's FX revenues. A positive estimator for the export ratio indicates that companies tend to adjust their debt and income to the foreign exchange composition. As shown in the table, the coefficient of the export rate is positive and statistically significant. This result implies that the companies' revenues tend to match the foreign exchange composition. This finding supports the view that in the literature, companies are able to borrow more in FX and hedge against exchange rate risk, thereby alleviating their financial constraints. (Kalemli-Özcan et al.2009 and 2010; Alp \& Yalçın 2015).
The high ratio of net tangible assets to total assets (NTA) reduces the asymmetric information problem, allowing firms to borrow at a higher level (Pratap et al. 2003). In practice, it is estimated that dollarization increases as the NTA, which is a signalling feature for companies' collateral, increases.

The leverage ratio (LR) reflects the borrowing capacity of companies. A statistically significant positive correlation was estimated between the leverage ratio and the debt dollarization ratio. Estimations, in parallel with the findings in the literature, imply that the debt dollarization increases with the leverage ratio, which in turn affects firms' access to international financial funds positively.

All the macroeconomic variables ( $\triangle$ REER, INF) except for the political risk (PRI) are statistically significant. In the context of "portfolio approach", dollarization is related to the anticipated volatility in real exchange rate and in inflation. In high and volatile inflationary environments, economic units may prefer to trade in currencies with relatively low volatility. (Serdengeçti 2005; Başçı 2011). As a matter of fact, it is frequently emphasized that the dollarization is a protection method, developed against the uncertainties brought about by the inflationary environment (Levy-Yeyati \& Rey 2006). It is estimated 
that companies are more likely to have a dollarization tendency depending on the inflation rate. On the other hand, as mentioned in the study, dollarization is frequently emphasized as a protection against global risks and uncertainties. Therefore, the increase in real exchange rate decreases the tendency of dollarization depending on the first effect, whereas it increases the tendency of dollarization due to the second effect. So, the $\triangle$ REER coefficient is positive and statistically significant.

Political risk index, which is another macroeconomic variable, is to provide an assessment tool on the political stability of the country. In the study, the political risk index is considered as the determinant of debt dollarization and company performance in manufacturing firms. This study is thought to contribute to the literature on how political instability affects real sector borrowing costs and sales performance. According to the estimates, the coefficient of "political instability" variable is statistically insignificant. This finding reveals that companies are able to protect from foreign exchange risk which increased after the 2008 financial crisis. Table 5 shows the estimation results based on model 2. Here, the determinants of performance (based on the active profitability) of 15 sub-sectors are presented.

According to the model 2, the one-term lagged value of the probability variable $\left(\mathrm{PRO}_{\mathrm{t}-1}\right)$ is positive and statistically significant. This result shows that there is persistence in profitability. The political risk (PRI) variable is statistically insignificant. The variable $\left(\mathrm{DDR}_{\mathrm{it}-1}\right.$ $* \triangle$ REER $\left._{\mathrm{t}}\right)$, which is defined as the balance sheet effect in the model, was estimated to be negative. Accordingly, as the real exchange rate increases, borrowing costs will rise in sectors with FX debt. On the other hand, when the national currency appreciates, the cost of debt will decrease in sectors with FX debt. This is termed as a "negative balance sheet effect" in the literature. Accordingly, the balance sheet of companies with high debt dollarization deteriorates as the real exchange rate increase. The parameter $\left(\mathrm{EX}_{\mathrm{it}} * \Delta \mathrm{REER}_{\mathrm{t}}\right)$, which is defined as export or competition effect in the model is also statistically insignificant. The real exchange rate coefficient ( $\triangle$ REER) is positive, which means that the profitability of firms increases as expected.

\section{Conclusions and Recommendations}

It is frequently expressed by international institutions, academics and policy makers, in which the debt stock of the real sector, is one of the main sources of economic and financial fragility ${ }^{1}$. This article presents findings that this view may be valid. In fact, it has been found that real exchange rate increases have increased the competitive

1 For the detailed explanation related to economic and financial fragility, please see Bernanke and Bertner (1990). power of companies and this has increased profitability through export increases. On the other hand, evidence has been presented that the rise in political instability in the country has no impact on firm performance. In other words, the increase in real exchange rates and political instability diminishes profitability while worsening the debts of companies with high debt-dollarization and low exports. Besides, the analysis of the determinants of the debt dollarization, which is included in the study, is in parallel with the related studies. Accordingly, especially in flexible exchange rate regimes, the use of FX-denominated borrowing by companies with limited domestic credit facilities has made it more susceptible to exchange rate shocks and political instability. Thus, when considering this fragile structure, sudden and significant exchange rate fluctuations should be avoided in Turkey. The real sector's borrowing level and currency mismatch in foreign currency make Turkey's economy prone to economic crises. In this framework, companies are advised to use short-term derivatives to avoid exchange rate risk and, in the long run, to increase their FX-denominated revenues. On the other hand, to avoid exchange rate risk, it becomes important for companies to be competitive in export products that are less responsive to cyclical movements in international markets.

The above analysis reveals that companies can limit their negative balance sheet effects if they maintain a balance between their FX-denominated debt and FX-denominated income (natural conservation) and thus sustain profitability. The implementation of policies that enhance the competitiveness of companies in foreign markets allows them to borrow in low-cost FX-denominated loans while avoiding the negative balance sheet effects of these debts. Within this framework, more stable profit margins and growth rates are expected to be achieved only through the increase in export rates.

\section{REFERENCES}

[1] Aghion, P., Bacchetta, P., \& Banerjee, A. (2001). Currency crises and monetary policy in an economy with credit constraints. European Economic Review, 45(7), 1121-1150. https://doi.org/10.1016/S0014-2921(00)00100-8

[2] Aguiar, M. (2005). Investment, devaluation, and foreign currency exposure: The case of Mexico. Journal of Development Economics, 78(1), 95-113. https://doi.org/10. 1016/j.jdeveco.2004.06.012

[3] Aklan, N., \& Nargelecekenler, M. (2010). Yükümlülük dolarizasyonu ve bilanço etkisi: türkiye üzerine bir analiz. SIYASAL: Journal of Political Sciences, (43), 177-204.

[4] Allen, M., Rosenberg, C., Keller, C., Setser, B., \& Roubini, N. (2002). A Balance sheet approach to financial crisis. In A Balance Sheet Approach to Financial Crisis (Vol. 2). 
https://doi.org/10.5089/9781451957150.001.a001

[5] Alp, H. B., \& Yalçın, C. (2015). Türkiye'de Şirketlerin Borç Dolarizasyonu ve Büyüme Performansı (Liability Dollarization and Growth Performance of Non-Financial Firms in Turkey). Turkish, The Central Bank of Turkey Working Paper, (1501).

[6] Arellano, M., \& Bover, O. (1995). Another look at the instrumental variable estimation of error-components models. Journal of econometrics, 68(1), 29-51.

[7] Başç1, E. (2011). Türkiye'de Ters Dolarizasyon. Improvement. Conference of Improving Financing Through Local Currency and Local Capital Markets.

[8] Bebczuk, R., Galindo, A. ve Panizza, U. (2006). An Evaluation of the Contractionary Devaluation Hypothesis, Inter-American Development Bank Working Paper, No. 582.

[9] Bernanke, B., \& Gertler, M. (1990). Financial fragility and economic performance. The quarterly journal of economics, 105(1), 87-114.

[10] Bleakley, H., \& Cowan, K. (2008). Corporate dollar debt and depreciations: much ado about nothing? The Review of Economics and Statistics, 90(4), 612-626.

[11] Dornbusch, R. (2001). A Primer on Emerging-Market Crises. NBER Working Paper, No: 8326.

[12] Blundell, R., \& Bond, S. (1998). Initial conditions and moment restrictions in dynamic panel data models. Journal of econometrics, 87(1), 115-143.

[13] Bougheas, S., Lim, H., Mateut, S., Mizen, P., \& Yalcin, C. (2012). Lessons from the Asian Crisis: An Open Economy Credit Channel Model where Export Status Matters (No. 12/16).

[14] Calvo, G. A., \& Reinhart, C. M. (2002). Fear of floating. Quarterly Journal of Economics, 117(2), 379-408. https://d oi.org/10.1162/003355302753650274

[15] Calvo, G. A., Izquierdo, A., \& Mejia, L. F. (2004). On the empirics of sudden stops: the relevance of balance-sheet effects (No. w10520). National Bureau of Economic Research.

[16] C.B.R.T. (2016), "Financial Stability Report, CBRT Sectoral Balance Sheets," May, No 22.

[17] Céspedes, L. F., Chang, R., \& Velasco, A. (2004). Balance sheets and exchange rate policy. American Economic Review, 94(4), 1183-1193. https://doi.org/10.1257/0002828 042002589

[18] Cowan, K., Hansen, E., \& Herrera L. O. (2005) "Currency Mismatches, Balance Sheet Effects and Hedging in Chilean Non-Financial Corporations" Central Bank of Chile, Working Paper No: 346.

[19] Echeverry, J. C., Fergusson, L., Steiner, R., \& Aguilar, C. (2003). "Dollar" debt in Colombian firms: Are sinners punished during devaluations? Emerging Markets Review, 4(4), 417-449. https://doi.org/10.1016/S1566- 0141(03)000 $63-3$

[20] Eichengreen, B., \& Hausmann, R. (1999). Exchange Rates and Financial Fragility. https://doi.org/10.3386/w7418
[21] Frankel, J. A. (2005). Mundell-Fleming lecture: Contractionary currency crashes in developing countries. IMF Staff Papers, 52(2), 149-192.

[22] Galindo, A., Panizza, U., \& Schiantarelli, F. (2003). Debt composition and balance sheet effects of currency depreciation: A summary of the micro evidence. Emerging Markets Review, 4(4), 330-339. https://doi.org/10.1016/S1 566-0141(03)00059-1

[23] Gertler, M., Gilchrist, S., \& Natalucci, F. M. (2007). External constraints on monetary policy and the financial accelerator. Journal of Money, Credit and Banking, 39(2-3), 295-330. https://doi.org/10.1111/j.0022-2879.2007.00027.x

[24] Incekara, A., Mutlugın, B., \& Yilmaz, H. A. (2017). Borç Dolarizasyonunun Türk İmalat Sanayii Sektörü Büyümesi Üzerine Etkisi. Journal of Economic Policy Research, 4(1), 16-38.

[25] Kalemli-Ozcan, S., Kamil, H., \& Villegas-Sanchez, C. (2009). What Hinders Investment in The Aftermath of Financial Crises. NBER Working Paper.

[26] Kamil, H. (2012). How do exchange rate regimes affect firms' incentives to hedge currency risk? Micro evidence for Latin America (No. 12-69). International Monetary Fund.

[27] Krugman, P. (1999). Balance Sheets, the Transfer Problem, and Financial Crises. International Tax and Public Finance, 6(4), 459-472. https://doi.org/10.1023/A:1008741113074

[28] Levy-Yeyati, E., \& Rey, H. (2006). Financial dollarization: evaluating the consequences. Economic Policy, (January), $61-118$.

[29] Martínez, L., \& Werner, A. (2002). The exchange rate regime and the currency composition of corporate debt: The Mexican experience. Journal of Development Economics, 69(2), 315-334. https://doi.org/10.1016/S0304- 3878(02)00 091-3

[30] Mutlu, O., Ç. (2011), Türkiye'nin Kaynak Gereksinimi Çerçevesinde Reel Sektörün Dış Borçlanması, Gazi University Institute of Social Sciences, Department of Economics, Unpublished Doctoral Dissertation

[31] Obstfeld, M. (2009). International finance and growth in developing countries: what have we learned? IMF staff papers, 56(1), 63-111.

[32] Ozmen, E., \& Yalçın, C. (2007). Küresel finansal riskler karşısında Türkiye'de reel sektörün finansal yapısı ve borç d olarizasyonu. İktisat İşletme ve Finans, 22(258). https://do i.org/10.3848/iif.2007.258.2780

[33] Pratap, S., Lobato, I., \& Somuano, A. (2003). Debt composition and balance sheet effects of exchange rate volatility in Mexico: A firm level analysis. Emerging Markets Review, 4(4), 450-471. https://doi.org/10.1016/S1 566-0141(03)00064-5

[34] Ranciere, R., Tornell, A., \& Vamvakidis, M. A. (2010). A new index of currency mismatch and systemic risk (No. 10-263). International Monetary Fund.

[35] Roodman, D. (2009). How to do xtabond2: an introduction to difference and system GMM in Stata, The Stata Journal, 9(1), 86-136.

[36] Sanlisoy S., Aydın Ü. \& Yalcinkaya A. E. (2016), Politik 
Riskin Banka Karlılığ 1 Üzerine Etkisi, Proceedings of 1st International Conference on Scientific Cooperation for the Future in the Social Sciences, Uşak, 22-23 September 2016. 281-292

[37] Serdengeçti, S. (2005). Dolarizasyon/Ters Dolarizasyon. Ekim, Eskişehir.
[38] Windmeijer, F. (2005). "A finite sample correction for the variance of linear efficient two-step GMM estimators", Journal of Econometrics, 126, 25-51.

[39] Zettelmeyer, J., Nagy, P. M., \& Jeffrey, S. (2010). Addressing private sector currency mismatches in emerging Europe. In European Bank for Reconstruction and Development (EBRD) Working Paper. 